\title{
Tükörkép a V4-országok 2019. évi versenyképességéról
}

\section{Reflection on the Competitiveness of the V4 Countries in 2019}

\section{Összefoglalás}

A világgazdaság tengere hol kisebb, hol nagyobb hullámokat vet, ritka az a pillanat, amikor nem háborog. A szélcsend sem jó a vitorlázásnak, így mindnyájunknak el kell fogadni, hogy nem várhatunk a ,jobb” pillanatokra, hanem mindig az adott pillanat adottságainak, kihívásainak megfelelôen kell cselekedni. A V4-országok a politikai együttmúködésen túl ma már az európai gazdasági növekedés zálogát jelentik, így a tanulmány szerzóje azt a célt tûzte ki maga elé, hogy az egyre erôsödő gazdasági együttmúködés segítése érdekében a V4-országok 2019. évi versenyképességi helyzetérôl látleletet készít, és annak elemzése alapján rámutat az ezen országok elôtt álló feladatok hasonlóságára. Ehhez nemcsak a nagy nemzetközi elemzóintézmények 2019. évi elôrejelzéseit használja, hanem azok kritikai észrevételezése mellett kiegészítô mutatók bevonásának segítségével mutatja be átfogóan a V4-országok pozícióját.

Journal of Economic Literature (JEL) kódok: O1, O18, O57, I25, M12

Kulcsszavak: gazdasági fejlődés, regionális elemzés, országok összehasonlítása, képzés és gazdasági fejlôdés, személyzeti menedzsment

\section{Summary}

The "sea of the world economy" has either smaller or larger waves as it is a rare moment that it has no turbulence in it. Neither is the doldrum good for sailing, therefore we just all have to accept that we can not wait for "better moments" to come, but al-

Dr. ZöldRÉTI ATTILA a közgazdaság-tudomány kandidátusa, BFKH projektellenôrzési és kontrolling osztályvezetô (zoldretia@gmail.com). 
ways have to act according to the conditions and challenges of the actual moment. Beyond their political cooperation, today, the V4 countries (Czech Republic, Hungary, Poland, Slovakia) are now the key to economic growth in Europe. Thus, the author of this study undertook the task of reviewing and analyzing the state of competitiveness of V4 countries in 2019 and pointing out the similarity of the challenges facing V4 countries. For this work, the author use not only 2019 forecasts of major international analytical institutions, but also critically review them with the inclusion of additional indicators to be able to give a comprehensive presentation on the position of the V4 countries.

Journal of Economic Literature (JEL) codes: O1, O18, O57, I25, M12

Keywords: economic development, regional analysis, comparative studies of countries, education and economic development, personnel management

\section{BEVEZETÉS}

A gazdasági válságok mint búvópatakok hol eltûnnek a szemünk elól, hol pedig megújult erôvel törnek felszínre. Alig múlt el néhány jó év az utolsó nagy pénzügyi-gazdasági világválság sikeresnek ítélt kezelése óta, és máris egy újabb válság kialakulására utaló jeleket látunk. Ezért folyamatos erófeszítéseket kell tennünk annak érdekében, hogy helyesen érzékeljük és értékeljük mind az adott, mind pedig az elérendô pozíciónkat, annak érdekében, hogy helyes navigációval a kívánt célpontot tudjuk elérni. A Nagy Pompeiusként emlegetett császár a Szicíliából Rómába gabonát szállító hajósokat „buzdította”, hogy a viharos idô ellenére is hajózzanak ki a kikötóból. „Navigare necesse est, vivere non est necesse”, azaz: Hajózni muszáj, élni nem. Ez a „hajózni muszáj” ma is parancserejú motiváció a kereskedelem és az azzal összefüggó gazdasági teljesítmény fejlesztésére és növelésére, hiszen Földünk növekvô népességének fenntartható ellátása megköveteli a gazdasági teljesítmény növelését.

A földrajzi, gazdasági pozíciókért és piacokért folytatott világgazdasági verseny részeként a globális, regionális és lokális piac érintettjei és az erre szakosodott intézetek ma már folyamatosan értékelik a térségek, országok és a piaci szereplók gazdasági erejét és versenyképességét, a jövőben várható piaci részesedések alakulása, valamint az azokhoz tartozó belsố összefüggések feltárása érdekében. A vizsgálatok és azon belül a versenyképességi vizsgálatok módszertana nem egységes. Megalapozott vélemények már korábban is rámutattak arra, hogy a nagy nemzetközi intézmények versenyképességi mutatóiban a szubjektivitás is tetten érhetô, tehát torzított az általuk közvetített tükörkép. A tanulmány nem egy új versenyképességi mutató módszertanához, hanem a jelenleg alkalmazott versenyképességi mutatók kritikájához kíván további adalékok segítségével hozzájárulni, és rámutatni a szubjektivitásra, ezzel az általuk közvetített képet kívánja korrigálni. A tanulmány további célja arra is rámutatni, hogy bár elkerülhetetlen módon minden versenyképességi eljárás szerves része a humán erőforrás vizsgálata, vagyis 
annak elemzése, hogy a rendelkezésre álló humánkapacitás hogyan hat a gazdálkodásra és a versenyképességre, ezen a területen még jelentôs tartalékok állnak rendelkezésre. Különösen érvényes ez a magas humánpotenciállal rendelkezô tehetségek versenyképességgel összefüggő területén. A versenyképesség növelése szempontjából, érthető módon, kiemelt szerepet játszik az adott ország tehetségfelszívó és -megtartó képessége. Ez a V4-országok szempontjából is kiemelten fontos, hiszen a jó példákat követve cél az innovatív gazdaság elérése, abban pedig a humán tőke szerepe megkérdőjelezhetetlen.

\section{Az Európai Unió gazdasági KoHézióJÁnak és a V4-ORszágoK NÖVEKVŐ SZEREPÉNEK ÖSSZEFÜGGÉSEI}

Az Európai Unió (EU) 500 millió fốt meghaladó összlakossága által generált fogyasztás fontos hajtóereje az Unió gazdasági kohéziójának. Mindez már csak azzal a ténnyel is magyarázható, hogy ha az EU-t a lakosságszám szerint egységesnek tekintenénk, a harmadik legnagyobb lakosságszámmal rendelkezô ország lenne a világon. Ez a belsô szabályozással biztosítani kívánt, egységes belsô piachoz tartozó fogyasztás fontos kovásza és összetartó ereje a fogyasztásvezérelt világunkban az uniós gazdaságnak. Ennek tükrében érthetô, hogy az Európai Unió egyik legnagyobb horderejú vívmányának az egységes belsố piac megteremtése tekinthetô, hiszen a már említett 500 millió fốt meghaladó fogyasztói kapacitás által biztosított gazdasági hajtóerô képezi a hosszú távú uniós együttmúködés érdekeltségi alapját. Az alapelvek érvényesítése és az egységes piac múködése érdekében az uniós jogalkotók több száz jogszabályt fogadtak el az Unión belüli technikai, szabályozási és jogi akadályok elhárítása céljából. Egy sor olyan szakpolitikát dolgoztak ki az EU-ban, amelyek alapvetően befolyásolják a polgárok és a vállalkozások életét. Egyebek mellett ezek közé tartozik a versenypolitika, amelyben a tényleges verseny elôsegítése és fenntartása nem önmagában vett cél, hanem egy szabad és dinamikus, a belsô fogyasztás oldaláról vezérelt piac megvalósításának feltétele, amely egyúttal az általános gazdasági jólét elômozdításának is egyik eszköze.

A közösségi versenyszabályok alapvetô célja a torzulástól mentes szabadpiaci verseny biztosítása. A régi belsố vámakadályok felszámolását követôen ma már az áruk, a szolgáltatások és a tôke szabad áramlása is biztosított az egységes belsố piacon. A szabályozás nemcsak a belsô, hanem a külsô, harmadik fél irányában történô együttmúködésre is kiterjed, szem elôtt tartva az egységes belsố piac védelmét. Az egységes belsô piacon folytatott verseny az előzóeken túl azért is fontos az uniós vállalkozások számára, mert az ezen a piacon szerzett versenytapasztalat alapozza meg a helytállást és a további piacszerzést a világ egyéb piacain folytatott küzdelemben.

Üröm az örömben, hogy néhány EU-tagország, különösen az IMF 2019-es GDP-elórejelzésében a top 10-es pozícióban szereplô Németország, Franciaország, Nagy-Britannia és Olaszország, valóban kiemelkedóen szép teljesítményt ér el, de ebból sajnos feltételezhetô, hogy ezek az eredmények beárnyékolják az „együtt könnyebb és együtt erősebbek vagyunk" elv maradéktalan érvényesülését az EU-ban (IMF, 2019). Ez leginkább az egységes belpiac védelmének gyakorlatában (hiányában) nyilvánul meg, ahol esetükben mindenki csak a saját piacai védelmének mértékéig védi a közöset. 
Az elôzôek nyilvánvalóan szerepet játszanak az EU jövője szempontjából egyelőre nehezen belátható következményekkel járó Brexit esetében is, amelyet jelenleg az egységes belpiachoz kötődő közös érdekeltség helyett a centrifugális erô vezérel.

A 1. táblázatban az UN (2019) által nyilvántartott lakosságszámadatokat közöljük, amelyek gyakorlatilag megegyeznek a The World Bank és a The World Factbook adataival. A lista érdekessége, hogy az USA, lakosságszámát tekintve, a mintegy 330 millió lakosával a 3. a világban, amely nagyon fontos tényezó az USA belpiaca szempontjából. Mint tapasztaljuk, a jelen elnöki ciklusban megnyilvánuló kormányzati szándék erôteljesen védeni kívánja az USA belpiacát a belsô vállalkozások számára. Az is általánosan elfogadott, hogy a 300 millió fogyasztót meghaladó piac képes akár a saját fogyasztási kapacitása alapján is növekedési pályán maradni, így érthető a határozott fellépés ennek védelme érdekében. Ha ténylegesen hasonlóan erôteljes lépések védenék az EU belpiacát, biztos, hogy ismét felerôsödne a tagállamokra és a taggá válni akaró tagjelöltekre irányuló centripetális erô.

\section{1. táblázat: A Föld és azon belül a V4-országok lakosságszámának alakulása}

\begin{tabular}{l|l|r|r|c}
\hline \multirow{2}{*}{ Rangsor } & \multirow{2}{*}{ Ország } & \multicolumn{2}{|c|}{ Lakosság } & \multirow{2}{*}{ Megoszlás } \\
\cline { 3 - 5 } & & $\mathbf{2 0 1 8}$ & $\mathbf{2 0 1 9}$ & \\
\hline 1. & Kína & 1427647786 & 1433783686 & 18,6 \\
\hline 2. & India & 1352642280 & 1366417754 & 17,7 \\
\hline 3. & USA & 267096265 & 329064917 & 4,27 \\
\hline 4. & Indonézia & 212228286 & 216565318 & 2,51 \\
\hline 5. & Pakisztán & 209469323 & 211049527 & 2,74 \\
\hline 6. & Brazília & 195874683 & 200963599 & 2,61 \\
\hline 7. & Nigéria & 161376708 & 163046161 & 2,11 \\
\hline 8. & Banglades & 145734038 & 145872256 & 1,89 \\
\hline 9. & Oroszország & 126190788 & 127575529 & 1,65 \\
\hline 10. & Mexikó & & & \\
\hline$\ldots$ & & 37921592 & 37887768 & 0,491 \\
\hline 38. & Lengyelország & 10665677 & 10689209 & 0,139 \\
\hline 86. & Csehország & 9707499 & 9684679 & 0,126 \\
\hline 94. & Magyarország & 5452014 & 5457013 & 0,0707 \\
\hline 117. & Szlovákia & &
\end{tabular}

Forrás: The World Bank, 2019

Ha a táblázatban megvizsgáljuk a V4-országok összesített helyzetét, akkor azt tapasztaljuk, hogy a 2019-re prognosztizált 29113 fô csökkenés mellett összességében 63718669 fốt tesz ki a V4-országok összlakosságszáma. Ezzel az EU28-on belül Németországot, Nagy-Britanniát és Franciaországot követve, a V4-országok összlakossága alapján a 4. helyet foglalja el, megelőzve Olaszországot és Spanyolországot.

Ahhoz a tényhez, hogy a V4-országok jelentik Európa gazdasági növekedésének zálogát, a népesség és ezzel együtt a fogyasztói potenciál mellett további fontos tarta- 
lékot látunk, ha rápillantunk az Eurostat Regionális Évkönyv 2019. évi kiadványából idézett 1. ábrára (EC, 2019). Ezen az EU28-országok lakosságának medián életkor szerinti megoszlását látjuk 2018-as adatok alapján. Ebből egyértelmúen látszik, hogy a V4-országok lakosságának medián életkora alacsonyabb az EU15 országainál, ami a fogyasztóerôn túl a munkavállalási képességben rejlő tartalékokat is mutatja.

Mindezek megalapozzák és nyomatékosítják a V4-országok együttes politikai és gazdasági fellépését. Lengyelország és Magyarország esetében mutatkozó csökkenô lakosságszám tudatos beavatkozást igényel (Lentner et al., 2017), és indokolttá teszi a mindkét országban már megtett és folyamatban levô családvédelmi intézkedéseket. A cél nemcsak a népességszám csökkenésének megállítása, hanem ezzel együtt a társadalom elöregedési folyamatának megfordítása. Erre az EU15-nél jobb esélyt ad a V4-országok medián életkora, ami egyúttal most is azt jelenti, hogy ezen országok saját belsố humánerôforrás-kapacitásuk segítségével hosszú távon is képesek lesznek biztosítani a gazdasági fejlôdéshez szükséges szakképzett munkaerôt.

\section{A Föld GAZDASÁgI NÖVEKEDÉSÉNEK PROGNÓZISA}

A Föld lakosságszámának 2019-re előre jelzett növekedése 82337060 fốt tesz ki, ami gyakorlatilag egy év alatt egy, a mai Törökország lakosságszámával megegyezô növekedést jelent. Ugyanakkor az előrejelzések a népességszám növekedésének lassulását is jelzik, ami önmagában is reménykeltô. További bizakodásra ad okot, hogy a klímakatasztrófa jelei ellenére az idősorok elemzése és az előrejelzések alapján a Föld gazdasági összteljesítménye növekszik, és ez a tendencia várhatóan a következó években is így marad, mint ezt az 2. táblázat szemlélteti, és ezt mindenképpen pozitívumként kell értékelni.

2. táblázat: Az IMF elôrejelzése a Föld GDP-alakulásáról

\begin{tabular}{l|c|c}
\hline \multirow{2}{*}{ Év } & \multicolumn{2}{|c}{ GDP (Mrd dollár) } \\
\cline { 2 - 3 } & Nominális & Vásárlóeró-paritás (PPP) \\
\hline 2018 & 84835,46 & 135235,88 \\
\hline 2019 & 88081,13 & 143089,49 \\
\hline 2020 & 93084,96 & 151081,01 \\
\hline 2021 & 98016,89 & 159424,41 \\
\hline 2022 & 103262,90 & 168113,32 \\
\hline 2023 & 108712,27 & 177424,18 \\
\hline
\end{tabular}

Forrás: IMF

Mint mindenre, erre az optimista, világméretú és folyamatos GDP-növekedésre is többféle magyarázatot adnak a kutatók. A BBC egyik tanulmányában (Hét ok, amiért a Föld fejlôdik) arra hívja fel a figyelmet, hogy az aktuális gazdasági kilátások helyzete 
1. ábra: Az EU28-országok lakosságának medián életkor szerinti megoszlása (2018)

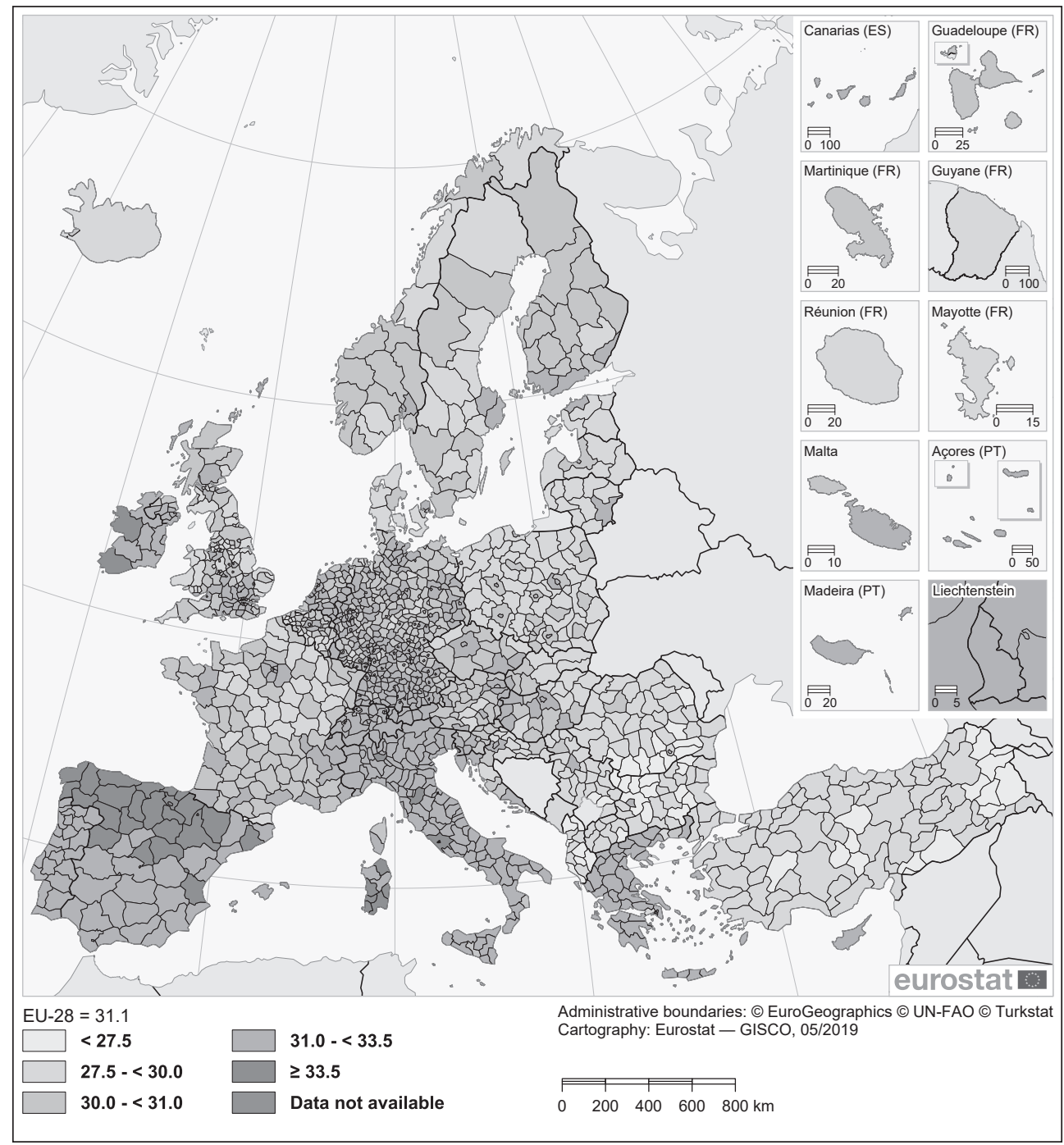

Forrás: EC, 2019

ma kedvezóbb a világban, mint azt az emberek többsége gondolja, amin nem is lehet csodálkozni, mert a hírek fókuszában napról napra folyamatosan csak a katasztrófák, a terroristatámadások, a háborúk és az éhínség áll (Probst, 2019). Ezzel szemben az idézett tanulmány szerint a helyzet jobb, mint korábban, mert:

- a várható élettartam folyamatosan emelkedik;

- a gyermekhalandóság folyamatosan csökken;

- a termékenységi ráta csökken (a legújabb előrejelzések a lakosságszám növekedési ütemének csökkenését prognosztizálják); 
- a GDP-növekedés tovább gyorsul,

- csökkent a globális jövedelmi egyenlőtlenség, szélesedett a fizetôképes kereslet globális megoszlása (az elmúlt kétszáz évben a Föld lakosságának növekedése mellett a napi egy fốre jutó jövedelem az európai, amerikai földrajzi területek mellett Ázsiában is erôs növekedést mutatott; sajnos Afrika lemaradása továbbra is jelentôs);

- több ember él demokráciában;

- csökken a konfliktusok száma és aránya.

Ha a felsorolt tényezôk mögé tekintünk, láthatjuk, hogy összességében ezen tényezók közvetlenül vagy közvetve a globális fizetóképes vásárlóerô erôsödését jelzik, amely bár továbbra sem egyenletes eloszlásban jelenik meg a Földön, de az elmaradt térségek fejlődésére is reményt ad.

AdAlÉKOK a V4-ORSZÁgoK 2019 -RE PROGNOSZTizÁlt

VERSENYKÉPESSÉGI MUTATÓINAK KRITIKÁJÁHOZ ÉS A KÖZÖS FELADATAINKHOZ

A nagy nemzetközi intézmények, amelyek a versenyképesség elemzésével foglalkoznak, mint például az Institute for Management Development (IMD), a Világgazdasági Fórum (World Economic Forum, WEF) vagy a Világbank, már évtizedek óta minden évben közzéteszik a versenyképesség alakulásáról készített prognózisukat és beszámolójukat. Nem egységes, de általános elfogadott értelmezésükben egy nemzetgazdaság versenyképessége azt mutatja meg, hogy mennyire képes egy ország olyan környezetet teremteni, termékek és szolgáltatások előállításával új hozzáadott értéket előállítani, amelyeknek a versengó piaci körülmények közötti értékesítése erôsíti a gazdaság szereplőit, egyidejúleg a lakosság életszínvonalának és életminôségének növelését is eredményezi.

Mivel maga a versenyképesség fogalmának értelmezése sem egységes, így a versenyképességi elemzések elméleti és módszertani alapjai egymástól különböznek. Vizsgálataikban különbözố területekre, pillérekre különbözô tartalmú és számosságú mutatót, különbözô számú szakértô bevonásával alkalmaznak. Mindez sokszor még a saját, korábbi évi eredményeikkel való összehasonlíthatóságát is nehezíti, nem is beszélve a különbözố mutatók összehasonlíthatóságáról.

A hazai szerzôk már évek óta megalapozott kritikát fejtenek ki a különbözô versenyképességi mutatókkal szemben. Az MNB elemzői már többször felhívták a figyelmet a szubjektivitás szerepére és az abból fakadó problémákra. Baksay és szerzótársai már 2017-ben rámutattak, hogy a WEF Global Competitiveness Report nevú versenyképességi rangsora, amely az egyik legismertebb versenyképességi értékelésnek számít világszerte, megalapozottsága tekintetében nem ad megbízható eredményt, ezért az csak kellő óvatossággal és kritikával használható (Baksay et al., 2017a). Az objektív értékelés érdekében, jelen tanulmány szerzôjéhez hasonlóan, ók is további mutatók bevonásának szükségességére mutatnak rá.

A 2017. évi nemzetközi versenyképességi prognózisokkal kapcsolatban az ÁSZ szakértôi is felhívták a figyelmet arra, hogy hazánk gazdasági teljesítménye szinte 
minden fontos index tekintetében évrôl évre erôsödik, a WEF és az IMD által készített versenyképességi rangsorokon ennek ellenére Magyarország indokolatlanul rosszul szerepelt (Simon-Lengyel, 2019). Ezek megalapozott észrevételek, ezért jelen tanulmány szerzője az alábbiakban összeveti egymással ezen prognózisokat, és további mutatók bevonásával kritikát fogalmaz meg a nemzetközi intézmények 2019. évi versenyképességi prognózisára vonatkozóan, és az objektív versenyképesség megállapítása érdekében további, a gazdasági teljesítményt jobban hangsúlyozó mutatók bevonását ajánlja. Álláspontja szerint az országok versenyképességi rangsora nem állhat ellentmondásban az adott ország gazdasági erejével, de mint a 4. táblázatból láthatjuk, az összevetés eredménye nem mutatja ezt egyértelmúen. A versenyképességgel foglalkozó intézmények mutatóiban tapasztalható ellentmondás különösen Kína esetében igaz, amely egyik nevesített intézményi versenyképességi rangsorban sem szerepel az elsố 10-ben, holott a GDP-rangsor és a versenyképes nagyvállalatainak száma szerint is 2. a világon. Hasonlóan ellentmondásos Japán versenyképességének jelzése is.

A szerzó álláspontja szerint az országok gazdasági erejének rangsorát a GDP objektívnek nevezhetô mutatója alapján el lehet fogadni. ${ }^{1}$ Az egy főre vetített GDP pedig a hatékonyság jobb feltárását segíti. A versenyképes nagyvállalatok száma is egzakt módon mutatja az adott ország piaci versenyben elfoglalt helyét. A Forbes Global 2000 listája minden szubjektivitást nélkülözô négy mutató (árbevétel, nettó profit, mérlegfôösszeg, piaci kapitalizáció) alapján rangsorolja a vállalatokat (2. ábra). A nagyvállalatok országonkénti megoszlását tekintve az eredmények mutatják, micsoda versenyfutás folyik az utóbbi években az USA és Kína között a nagyvállalatok területén.

A 2019. évi Global 2000 rangsor szerint tíz ország a 2000-ból 1520 vállalatot birtokol, azaz a vállalatok 76\%-át (ez a tíz ország szerepel a 4. táblázat szerinti összefoglaló kimutatásban is). A maradék 24\%-ot kitevô 480 vállalaton osztozik a többi ország, köztük a V4-hez tartozó Lengyelország 7, Magyarország 2, Csehország 1 nagyvállalattal. Szlovákia nem szerepel a listán. Az Ausztriával való összevetéshez megjegyezzük, hogy nyugati szomszédunk 9 vállalattal jelenik meg a listán. A V4-es országok Global 2000 listán szereplő nagyvállalatai országonkénti megoszlását szemlélteti a 3. táblázat. A nagyvállalatok mellett ugyanakkor nem szabad megfeledkezni a kkv-k innovációs és ezzel együtt versenyképességi szerepéról sem.

Az elôzőek összefoglalásaként a 4. táblázat tartalmazza a szerzô által végrehajtott komplex összevetést, amelyet tovább árnyal a kiegészítô mutatók figyelembevételével. Elöljáróban a már nevesített három intézmény versenyképességi rangsorát vetjük öszsze a gazdasági teljesítményt tükrözô egy fơre esô GDP-(nominális és PPP) rangsorral, valamint a Global 2000 legnagyobb vállalatok országonkénti megoszlásának listájával. A szerzô azért tartja fontosnak bevonni az egy fốre esô GDP vásárlóerô-paritáson (PPP) mért rangsort, mert az alapján valamennyi V4-ország jobban pozicionált a gazdasági teljesítmény tekintetében. Vizsgálatunk céljának megfelelően a V4-ek eredményét kiemelten szemlélteti a táblázat. Kínát a három intézmény versenyképességi rangsorának hangsúlyos kritikájaként, Ausztriát pedig a kihívás nagyságának érzékeltetése miatt láthatjuk. 
2. ábra: A Forbes Global 2000 alapján a nagyvállalatok országonkénti megoszlása, 2019

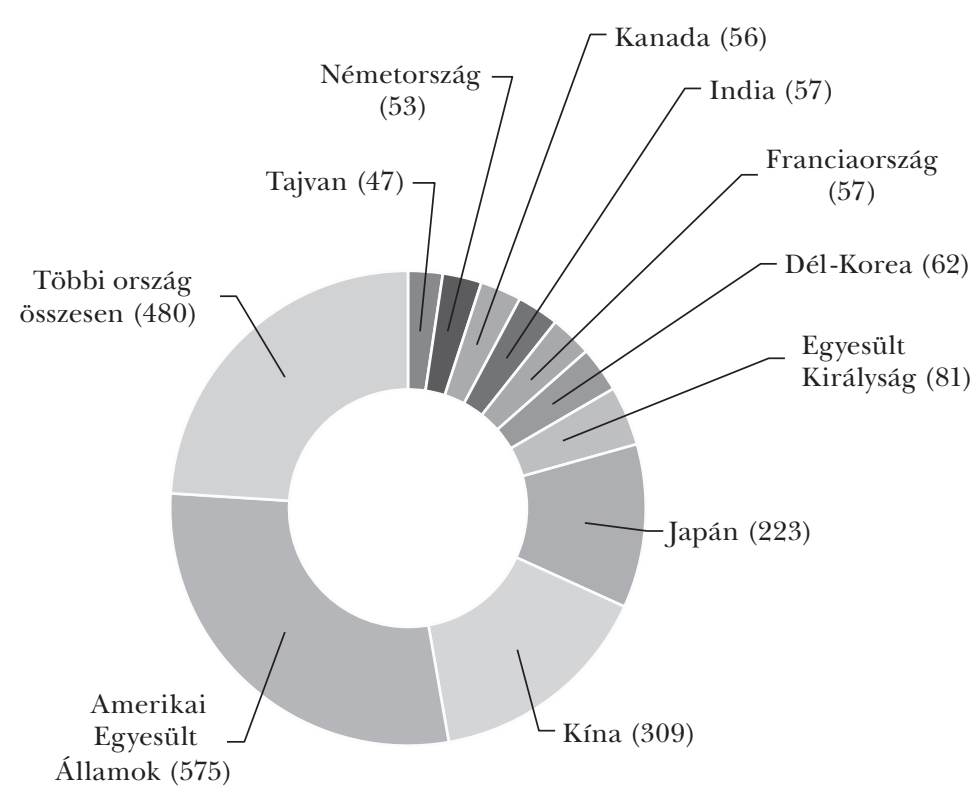

Forrás: Forbes, 2019

3. táblázat: A V4-országok nagyvállalatai a Forbes 2019-es Global 2000 listájában

\begin{tabular}{|c|c|c|c|c|c|c|}
\hline Helyezés & Ország & Vállalat & 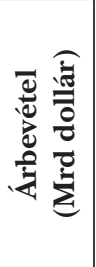 & 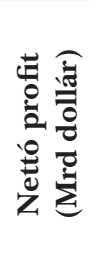 & 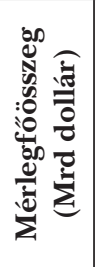 & 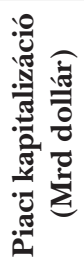 \\
\hline 964. & Csehország & CEZ Group & 8,3 & 0,475 & 32,3 & 12,6 \\
\hline 650. & Lengyelország & PKN Orlen & 30,4 & 1,60 & 17,1 & 11,4 \\
\hline 684. & Lengyelország & Grupa PZU & 10,4 & 0,888 & 87,1 & 9,6 \\
\hline 812. & Lengyelország & PKO Bank Polski & 4,7 & 1 & 86,3 & 12,9 \\
\hline 1009. & Lengyelország & Pging Group & 11,4 & 0,889 & 14,2 & 9,2 \\
\hline 1172. & Lengyelország & Bank Pekao & 2,6 & 0,633 & 50,9 & 8,1 \\
\hline 1619. & Lengyelország & PGE Polska Grupa Energetyczna & 7,2 & 0,415 & 20,2 & 4,7 \\
\hline 1990. & Lengyelország & Grupa LOTOS & 8,3 & 0,439 & 5,9 & 4,1 \\
\hline 868. & Magyarország & OTP Bank & 4,4 & 1,2 & 52 & 12 \\
\hline 886. & Magyarország & MOL Hungarian Oil & 19,1 & 1,1 & 16,4 & 7,4 \\
\hline
\end{tabular}

Forrás: Forbes, 2019 
4. táblázat: A versenyképességi mutatók összevetése az egy fốre esố GDP-, valamint a nagyvállalati rangsorral

\begin{tabular}{|c|c|c|c|c|c|c|}
\hline \multicolumn{4}{|c|}{$\begin{array}{l}\text { Versenyképességi mutatók összehasonlítása } \\
\qquad(2018-2019)\end{array}$} & $\begin{array}{c}\text { Egy főre esô } \\
\text { GDP (2019) } \\
\text { nominális }\end{array}$ & $\begin{array}{c}\text { Egy före eső } \\
\text { GDP (2019) } \\
\text { PPP }\end{array}$ & Ország/db \\
\hline & $\begin{array}{c}\text { IMD: } \\
\text { World } \\
\text { Competi- } \\
\text { tiveness } \\
\text { Report }\end{array}$ & $\begin{array}{l}\text { WEF: Global } \\
\text { Competi- } \\
\text { tiveness } \\
\text { Report GCI }\end{array}$ & $\begin{array}{c}\text { The World } \\
\text { Bank: } \\
\text { Doing } \\
\text { Business }\end{array}$ & IMF & IMF & $\begin{array}{c}\text { Forbes } \\
\text { Global } 2000\end{array}$ \\
\hline $\begin{array}{l}\text { Vizsgált } \\
\text { országok } \\
\text { száma }\end{array}$ & 63,00 & 140,00 & 190,0 & 193,00 & 193,0 & $2000 \mathrm{db}$ vállalat \\
\hline $\begin{array}{l}\text { Vizsgált } \\
\text { mutatók } \\
\text { száma }\end{array}$ & 332,00 & 98,00 & 11,0 & GDP & GDP & 4,0 \\
\hline \multicolumn{7}{|c|}{ Rangsor } \\
\hline 1. & Szingapúr & USA & Új-Zéland & Luxemburg & Katar & USA/575 \\
\hline 2. & Hongkong & Szingapúr & Szingapúr & Makaó & Makaó & Kína/309 \\
\hline 3. & USA & Németország & Dánia & Svájc & Luxemburg & Japán/223 \\
\hline 4. & Svájc & Svájc & Hongkong & Norvégia & Szingapúr & Egyesült Kir./81 \\
\hline 5. & $\begin{array}{l}\text { Egyesült } \\
\text { Arab Em. }\end{array}$ & Japán & Dél-Korea & Írország & Brunei & Dél-Korea/62 \\
\hline 6. & Hollandia & Hollandia & Grúzia & Katar & Írország & Franciao./57 \\
\hline 7. & Írország & Hongkong & Norvégia & USA & Norvégia & India/57 \\
\hline 8. & Dánia & $\begin{array}{l}\text { Egyesült } \\
\text { Királyság }\end{array}$ & USA & Szingapúr & $\begin{array}{l}\text { Egyesült } \\
\text { Arab Em. }\end{array}$ & Kanada/56 \\
\hline 9. & Svédország & Svédország & $\begin{array}{l}\text { Egyesült } \\
\text { Királyság }\end{array}$ & Dánia & Kuvait & Németo./53 \\
\hline 10. & Katar & Dánia & Macedónia & Ausztrália & Hongkong & Tajvan/47 \\
\hline
\end{tabular}

\begin{tabular}{l|c|c|c|c|c|c}
\hline & \multicolumn{5}{|c|}{ Rangsor } & Vállalatok száma \\
\hline Ausztria & 19 & 22 & 26 & 14 & 20 & $9 \mathrm{db}$ \\
\hline Csehország & 33 & 29 & 35 & 40 & 38 & $1 \mathrm{db}$ \\
\hline Lengyelo. & 38 & 37 & 33 & 59 & 46 & $7 \mathrm{db}$ \\
\hline Magyaro. & 47 & 48 & 53 & 56 & 48 & $2 \mathrm{db}$ \\
\hline Szlovákia & 53 & 41 & 42 & 45 & 42 & - \\
\hline Kína & 14 & 28 & 46 & 72 & 75 & $309 /$ Kína \\
\hline
\end{tabular}

Forrás: Saját szerkesztés

Ha az egy fôre esố vásárlóerô-paritáson vett GDP rangsoraival vetjük össze a nemzetközi intézmények versenyképességi prognózisát, láthatjuk, hogy Csehország és Lengyelország esetében jobb, Magyarország és Szlovákia esetében viszont rosszabb vagy azonos versenyképességi mutatókat közöltek, ami a már említett szubjektivitást jelzi. Mindezekkel szemben fontos tény, hogy az IMF 2019-es GDP-előrejelzése alapján a 
térségi megközelítés szempontjából, ha a V4-országok együttes GDP-összteljesítményét nézzük, akkor az EU-ban a 6., a világrangsorban pedig a 16. helyre jogosítja fel a V4-eket, amely indokolja az együttmúködés további erôsítését.

A V4-országok nemzetközi intézmények által prognosztizált mutatói alapján megállapítható, hogy azok nem megalapozott tükörképet mutatnak, hiszen ha csak Magyarországot nézzük, látható, hogy a válságkezelés (Baksay et al., 2017b), majd az egyensúly elérése után elindult növekedés (Matolcsy, 2015) és a felzárkózás útján halad az ország (Matolcsy-Palotai, 2019). A már évekkel ezelốtt bekövetkezett fordulat eredményeképpen több éve az uniós átlagot meghaladóan nô a visegrádi országok GDP-je. „A magyar gazdaság teljesítménye 2018-ban 4,9\%-kal emelkedett az egy ével korábbihoz képest, így a 2013-ban kezdôdött gazdasági konjunktúra 2018-ban is folytatódott. Gazdaságunk bôvülésének üteme illeszkedett a térségünk országait jellemzố GDP-növekedéshez. 2018 során a visegrádi országok az uniós átlagot (1,9\%) meghaladóan emelkedtek, miközben az EU gazdasága és ezen belül a fontosabb nemzetgazdaságok lanyhuló ütemben növekedtek" (KSH, 2019:10). Ez az évek óta zajló konjunktúra 2019-ben is folytatódik, és mind a négy visegrádi ország növekedése továbbra is meghaladja az EU28 átlagát. Mindez kedvezó és nagyon fontos is annak érdekében, hogy tovább növekedjen a V4-országok súlya. Ugyanakkor, mint ezt láthatjuk, ezen eredmények nem tükrözódnek a nemzetközi intézmények mutatóiban!

Az IMD több évre visszatekintô értékelésében láthatjuk, hogy Magyarország stagnáló, 47. helyre sorolt értékelése és Lengyelország 38 . helyre romló minősítése ellentmondásban van az országok GDP-növekedésével, hiszen a GDP Magyarországon 2018ban 4,9\%-kal, Lengyelországban pedig 5,1\%-kal emelkedett. Az elózóekben idézett KSH-statisztika alapján ugyanez igaz Csehországra és Szlovákiára is, tehát az IMD által visszavetített versenyképességi tükörkép nem mutatja objektív módon a V4-országokban évek óta zajló növekedést (3. ábra).

Magyarország tekintetében érdemes a történelmi hátteret is felidézni. Az ÁSZ ellenőrzési jelentésében rámutat az állami források felhasználásának hiányosságaira. A több mint tízéves jelentést azért idézi a szerzô, hogy tanuljunk belóle, és kerüljük el az akkor elkövetett hibákat (ÁSZ, 2008). A jelentés szerint az állam által támogatott gazdaságfejlesztés, amelynek fogalma és tartalma nehezen beszorítható az államháztartás rendszerébe, önmagában nem csupán forráskérdés. A vizsgált 2004-2006-os idôszakban, a közel 1500 Mrd Ft összegú gazdaságfejlesztési jellegú államháztartási kiadásokhoz nem alakították ki a társadalmi-gazdasági fejlesztések átfogó stratégiáját, ebbốl kifolyólag nem volt megoldott a fejlesztési célokat szolgáló erőforrások összhangja. A tervezési és szabályozási elmaradások miatt az ellenőrzött idôszakban nem valósult meg a gazdaságfejlesztés területére irányuló direkt és indirekt állami eszközök és erőforrások alkalmazásának szabályozott harmonizációja. Az összehangolás és harmonizáció hiánya akadályozta az eszközfelhasználás haszonmaximalizálását.

Az idézett ÁSZ-jelentés kiemeli, hogy a világgazdasági versenyben alkalmazható állami eszközöket (milyen célokra, milyen területeken nyújtható támogatás állami forrásból, beleértve az adó- és kamatkedvezményeket is) egyértelmúen meghatározza az 
3. ábra: Közép- és Kelet-Európa országainak az IMD versenyképességi mutatója szerinti rangsora alakulása

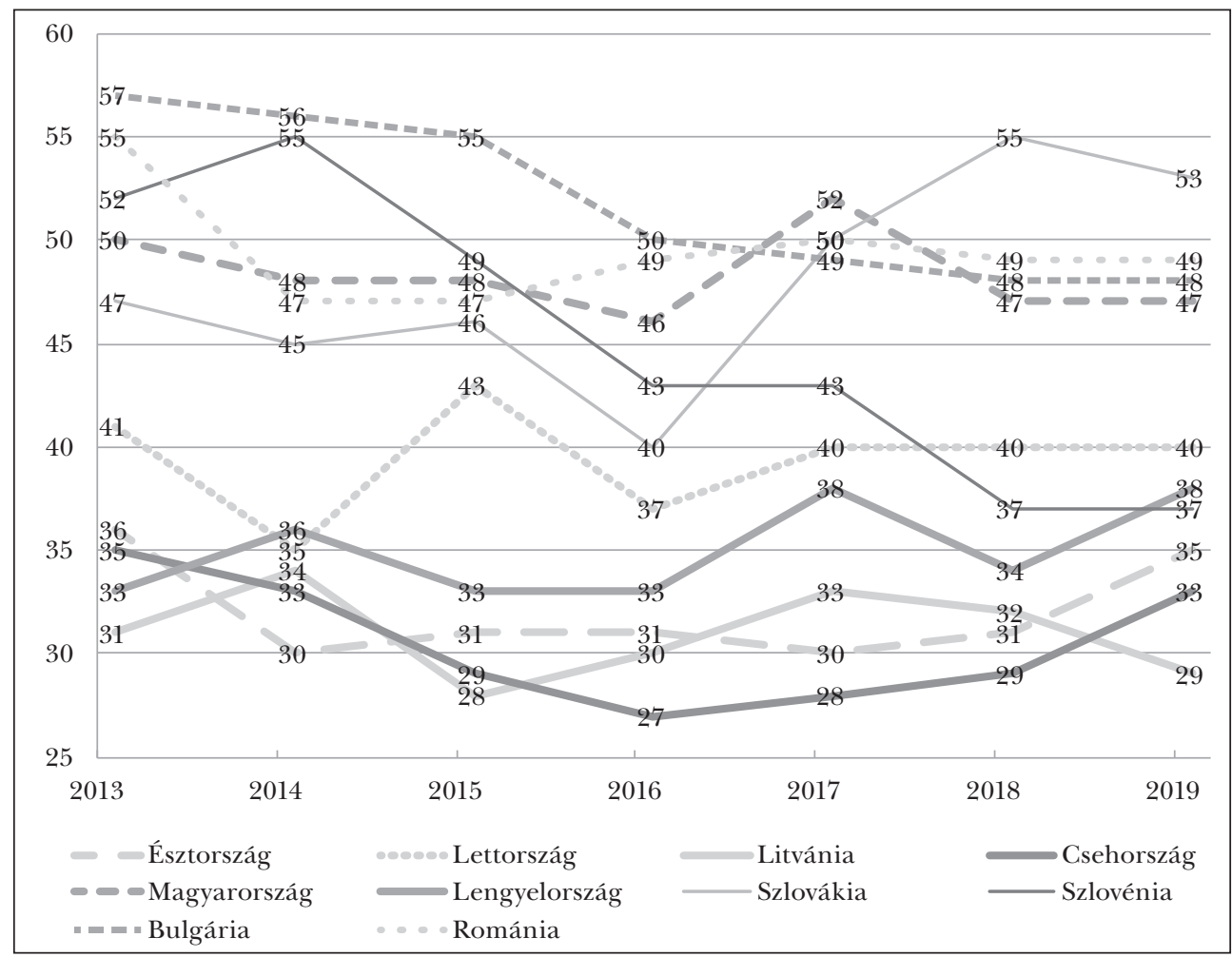

Forrás: IMD, 2019

Európai Unió versenyjoga. A közösségi versenyjog elismeri, hogy szükség lehet a nemzeti vállalatoknak és iparágaknak nyújtott támogatásokra, de tilt minden olyan tagállami forrásból nyújtott támogatást, amely torzítja a versenyt, és meghatározza azokat a területeket is, ahol a szabályozott szintú támogatás megengedett, pl. a foglalkoztatás javítására, képzésre, energiamegtakarításra, regionális célokra, környezetvédelemre, kutatás-fejlesztésre, valamint kis- és középvállalatok részére nyújtott támogatások. A jelentés tartalmazza, hogy az IMD World Competitiveness Yearbook 2000 és 2007. évi adatai alapján Magyarország a világ versenyképességi rangsorában 2007-ben nyolc hellyel rosszabb pozícióval rendelkezett, mint 2000-ben.

Az EU területi kohéziója és regionális politikája eredményeinek további sajátos látlelete az EU28 és a V4-országok jelentôs területi, regionális szórása a GDP elóállításában. Mindezek a regionális különbségek mellett a versenyképességben játszanak szerepet. Az Eurostat 34/2019. számában, 2019. február 26-án számolt be az EU28 régióinak szórásáról az egy főre vetített GDP alapján (Eurostat, 2019). Az olló igen tágra nyitott, hiszen az EU28 régióinak átlagához képest (100\%) London központja a maga 626\%-ával tornyosul az élre, szemben a legszegényebb északnyugat-bolgár régió 
31\%-ával. Sajnos ebben a nagy szórásban a V4-országok régiói is érintettek. Prága és Pozsony a maguk 7., illetve 8. helyezésével kiemelkedó helyet foglalnak el a top 10-es listában, de az olló másik ágán, a legszegényebb 20 régióban 4 magyar és 3 lengyel régió is szerepel. A V4-országok régióinak átlagát, a fóvárosok eredményét a jelentésból kiemelve a 5. táblázat mutatja. Ismét láthatjuk Ausztria hasonló eredményeit az összehasonlítás érdekében. Az eredmények alapján az egész EU-nak, az összes visegrádi országnak és különösen Magyarországnak és Lengyelországnak van kiemelt közös feladata a területi kohézió és a regionális versenyképesség javítása területén.

5. táblázat: Az EU28-régiók egy fốre esố GDP-átlagához (100\%) viszonyítva a V4-es régiók átlageredményei és az egyes fốvárosok teljesítménye

\begin{tabular}{l|c|c}
\hline Ország megnevezése & Régiók átlaga (NUTS2) & Fóváros \\
\hline EU28 & $100 \%$ & Brüsszel $/ 196 \%$ \\
\hline Csehország & $89 \%$ & Prága $/ 187 \%$ \\
\hline Lengyelország & $70 \%$ & Varsó $/ 152 \%$ \\
\hline Magyarország & $68 \%$ & Budapest $/ 139 \%$ \\
\hline Szlovákia & $76 \%$ & Pozsony $/ 179 \%$ \\
\hline Ausztria & $127 \%$ & Bécs $/ 151 \%$ \\
\hline
\end{tabular}

Forrás: Eurostat, 2019

További, a versenyképességet befolyásoló adalékként a humánkapacitások hatékony alkalmazásával összefüggésben érdemes megvizsgálni a versenyhelyzet elemzésével foglalkozó, már többször hivatkozott IMD World Competitiveness Centernek az IMD World Talent Ranking 2018 címen publikált felmérését, amely azt rangsorolta, hogy a felmérésben részt vevô 63 ország és az ott múködő vállalati szektor mennyire képes vonzóvá tenni saját magát a tehetséges munkavállalók számára (IMD, 2018). Azt vizsgálták, hogy az országok hogyan teljesítenek a legkülönbözóbb területeken. Idetartoznak a közvetlen bérjellegú motiváción kívül az oktatás, a gyakornoki képzés, a munkahelyi képzés, a nyelvtudás, a megélhetési költségek, a javadalmazás és az adók mértéke, valamint az általános életminôségre és a társadalmi környezetre vonatkozó szempontok.

A 6. táblázatban az IMD World Talent Ranking 2018 összefoglaló listáját láthatjuk az országok rangsorával. A táblázat és a publikáció adatai alapján két dolog biztosan látszik. Svájc az elmúlt öt évben töretlenül tartja vezetô szerepét. A V4-országok közül Csehország és Lengyelország vonzási képessége meghaladja Magyarország és Szlovákia ilyen képességét. A szerzô célja és felvállalt feladata, hogy a jó példákat elemezve, ajánlásokkal segítse a magyar országimázs fejlődését és a magyar tehetségek hatékony kibontakoztatását. Ennek keretében felhívja a figyelmet a tehetségmenedzsment minél szélesebb körú elterjesztésének támogatására, hiszen a módszertan hatékony alkalmazása segítheti a magyar és a V4-országok kkv-szektorának bekapcsolódását az innovációs versenybe. 
6. táblázat: A V4-országok helyezései az IMD World Talent Ranking 2018 eredménylistájából

\begin{tabular}{c|l|c|c|c|c}
\hline $\begin{array}{c}\text { Összesített } \\
\text { rangsor } \\
2018\end{array}$ & \multicolumn{2}{|c|}{ Ország } & \multicolumn{2}{|c|}{ Éves változás } & \multicolumn{2}{c}{ Összpontszám 2018 } \\
\hline 1 & Svájc & & 0 & & 100,00 \\
\hline 2 & Dánia & & 0 & & 91,97 \\
\hline 3 & Norvégia & + & 4 & & 86,37 \\
\hline 4 & Ausztria & & 0 & & 86,10 \\
\hline 5 & Hollandia & + & 1 & & 85,25 \\
\hline 6 & Kanada & + & 5 & & 84,50 \\
\hline 7 & Finnország & - & 2 & & 83,00 \\
\hline 8 & Svédország & + & 1 & & 82,45 \\
\hline 9 & Luxemburg & + & 1 & & 81,63 \\
\hline 10 & Németország & - & 2 & & 81,11 \\
\hline$\ldots$ & & & & & \\
\hline 37 & Csehország & + & 1 & & 61,02 \\
\hline 38 & Lengyelország & - & 4 & & 60,81 \\
\hline 49 & Magyarország & + & 5 & & 47,76 \\
\hline 59 & Szlovákia & - & 13 & & 39,63 \\
\hline
\end{tabular}

Forrás: IMD, 2018:24-25

A tehetségek hatékony alkalmazására a módszertan ismert, és gyakorlati alkalmazása ajánlott (Thom-Zöldréti, 2019). Mindez azért fontos, mert a tehetségek kiválasztása, felkészítése és motiválása a szakképzéstôl kezdve a legmagasabban képzett, a tudományos kutatási munkához kapcsolódó területeken is kiemelkedő szerepet játszik az adott vállalkozás és az ország versenyképessége szempontjából (Lentner, 2007), ezért hazánkban és a V4-országokban is érthetô és szükséges módon, az elért eredmények mellett, további erôfeszítéseket kell tenni ezen a területen is.

A humánkapacitás és azon belül a tehetségek hatékony alkalmazásához kapcsolódóan a munkaerô vonzására, a környezet és a közösség fontosságára a BCG/WFPMAegyüttmúködés publikációja is rámutat (BCG, 2014). Felmérésük szerint a munkahelyválasztásnál a foglalkoztatottak számára a munkakultúra szempontjai fontosabbak az anyagi szempontoknál. Ez a fiatal tehetségek munkaválasztásánál különösen lényeges, hiszen esetükben, egy versenyzó jövôképból kiindulva, nagyobb hangsúllyal szerepelnek a szakmai megbecsüléssel, a sikerrel és elismeréssel összefüggó szempontok, mint a pénzügyiek.

Az előzőeken túl, tovább hangsúlyozva a magasan képzett szakemberek versenyképességre gyakorolt, kiemelkedô szerepének fontosságát, örömteli hír, hogy a QS World University Rankings 2020-as listájának tanúsága szerint hat magyar egyetem is szerepel a világ ezer legjobb egyeteme között. A legelőkelőbb helyezést a Szegedi Tudományegyetem érte el, amely a lista 501-510. helyén szerepel. A Debreceni Egyetem a 601-650., az ELTE és a Pécsi Tudományegyetem a 650-700., a Budapesti Múszaki 
és Gazdaságtudományi Egyetem és a Budapesti Corvinus Egyetem pedig a 801-1000. helyezett jelenleg a nemzetközi listán. Sôt, ha nem az összevont egyetemi rangsort, hanem a szakterületek szerinti rangsort nézzük, akkor tíz magyar képzési terület szerepel a listán. Magyarországhoz hasonlóan a többi V4-ország is reményteljes eredményt ért el az egyetemek rangsorban szereplố számát tekintve. Elérendô közös célkitúzés, hogy a V4-országok egyetemei minél hamarabb a rangsor elsô 200 helyezettje között szerepeljenek. Erre meg is van a közös akarat (7. táblázat).

7. táblázat: A V4-országok egyetemeinek száma a QS World University Rankings 2020-as listáján

\begin{tabular}{l|c}
\hline Ország megnevezése & Egyetemek száma a listán \\
\hline Csehország & 9 \\
\hline Lengyelország & 16 \\
\hline Magyarország & 6 \\
\hline Szlovákia & 3 \\
\hline
\end{tabular}

Forrás: QS Top Universities, 2019

\section{KöveTKEZTETÉS ÉS KITEKINTÉS}

A V4-országok 2019. évi, a nemzetközi intézetek által közölt versenyképességi előrejelzéseivel összefüggésben az elôzôekben bemutatott összehasonlító módszertan és tényezôk együttes eredménye alapján megállapíthatjuk, hogy azok szubjektivitást is tükröznek, így azok használatát csak ennek ismeretében lehet használni. Az eredmények azt mutatják, hogy az elmúlt években elért növekedés megalapozza a felzárkózást, ennek ellenére jelenleg a V4-országok egyike sem érte még el a hosszabb távon célként kitûzött teljes versenyképességi fordulatot, így ez közös kihívást jelent valamennyi V4-ország számára.

Ugyanakkor a versenyképesség elemzésével foglalkozó nemzetközi intézetek mutatóival szemben a megfogalmazott kritika jelen vizsgálat eredményei alapján jogosnak tûnik, a szubjektivitásra és a gazdasági teljesítmény nem kellô és nem egyenlô arányú figyelembevételére az általuk prognosztizált rangsorok elsô 10 helyezettje tekintetében egyértelmúen rámutat a tanulmány. A gazdasági teljesítmény nem egységes figyelembevételét a V4-országok esetében is tetten érhetjük a tanulmány igazolása alapján. A vizsgálatba bevont valamennyi mutató tekintetében egybecsengés van abban, hogy Csehország és Lengyelország jelenleg kedvezôbb versenyképességi pozíciót mutat, mint Magyarország és Szlovákia. Ugyanakkor, ha az egy fốre esô vásárlóerô-paritáson vett GDP-rangsorokkal vetjük össze a nemzetközi intézmények versenyképességi prognózisát, láthatjuk, hogy Csehország és Lengyelország esetében jobb, Magyarország és Szlovákia esetében viszont rosszabb vagy azonos versenyképességi mutatókat közöltek a nemzetközi versenyképességet minôsítô intézmények, ami a már említett szubjektivitást jelzi.

Magyarország esetében közel tízéves fejlődés után mára sikerült Európa legdinamikusabban fejlôdô gazdaságává válnia. A megtermelt költségvetési forrásokból, egye- 
bek mellett, folyamatosan emelkedik a bérekre, az egészségügyi ellátásra és az oktatásra, tehát a fogyasztásra és a humánkapacitás fejlesztésére fordított kiadások aránya. Mindezek segítik a fogyasztás bővülését és a szakképzett humán erőforrás biztosítását a gazdaság számára, ezek pedig visszahatnak a gazdaság és versenyképesség elóbbre jutására (Lentner, 2015; 2019). Mindezen eredményeket egyelőre nem igazolják viszsza a nemzetközi intézetek versenyképességi mutatói. Ugyanakkor gazdaságpolitikánk lényegének abban kell állnia, hogy évtizedeken átívelően stabilitást és gyarapodást biztosítson (Matolcsy, 2015).

Az EU-ban folyó felfokozott piaci versenyben a többi szereplóvel szemben - elsôsorban azok történelmileg kialakult előnyeik további érvényesítési képessége és kihasználása miatt - a V4-országok az elmúlt években sem a versenyképességben, sem a gazdasági eredmények tekintetében nem tudták átrendezni a sorrendet. Tehát hangsúlyozni kell, nem arról van szó, hogy a V4-országok tétlenkedtek volna az elmúlt években, hanem arról, hogy jól felfogott érdekeiket képviselve a többi tagország is „foggal-körömmel” harcol a piaci pozícióinak, gazdasági teljesítményeinek megtartásáért és fejlesztéséért. Mindezekból kiindulva azt is látni kell, hogy a V4-országok csak további szoros gazdasági együttmúködéssel tudják kihasználni és érvényesíteni a politikai és méretgazdasági előnyöket, és felszabadítani a fogyasztásban, valamint a foglalkoztatásban rejló tartalékaikat. A V4-országok mindegyike az elôzóekben felvázolt képet tisztán látja, és sorra dolgozza ki a cselekvési programjait versenyképessége javítása érdekében. Magyarország tekintetében a monitoring és a következetes végrehajtás is biztosított (Lambert, 2019), így megvalósítható az erőforrások összehangolt és harmonizált felhasználása.

Az EU kohéziós politikája ellenére az egész EU-ban és így a V4-országok régióiban is szinte változatlanul jelentôs gazdasági különbségek tapasztalhatók regionális szinten. Így a V4-es országok közös feladatainak sorába tartozik a regionális fejlettségi különbségek csökkentése is. Ebben különösen Magyarország és Lengyelország tekintetében kell a közeljövôben fordulatot elérni, hiszen a vidék megtartóképessége a fenntartható fejlődésnek is feltétele. A regionális versenyképesség fejlesztése mellett további közös cél és feladat, hogy az együttmúködô V4-országok összesített fogyasztási kapacitásában rejlő tartalékaikat saját gazdasági fejlôdésükre kölcsönösen használják ki. Ehhez tovább kell erősíteni a már eddig is szép sikereket elért társadalmi és gazdasági együttmúködést.

Magyarország tekintetében hasonló következtetésre jutott az MNB és a kormány, és meg is tették a maguk szükséges lépéseit. Idesorolható az MNB Versenyképességi Programja, a Nemzeti Versenyképességi Tanács által kidolgozott Program a Versenyképesebb Magyarországért, valamint a kormány által kiadott Magyarország 2019. évi Nemzeti Reform Programja (MNB, 2019; Nemzeti Versenyképességi Tanács, 2019; Magyarország Kormánya, 2019). Az egész nemzet jövőjét és azon belül a versenyképességi potenciálok javítását tartalmazzák a Családvédelmi Akciótervben, a Gazdaságvédelmi Akciótervben és a Magyar Falu Programban lefektetett célok és a megvalósításukat szolgáló eszközök. A helyzet és a felsorolt programokban, akciótervekben lefektetett irányok és célok világosak, az EU28 átlagát meghaladó gazdasági növeke- 


\section{Zöldréti Attila: Tükörkép a V4-országok 2019. évi versenyképességéról}

dés pedig feszíti a vitorláinkat, így most már csak, ahogy a Nagy Pompeius mondja, „Navigare necesse est”, vagyis hajózni kell céljaink felé, bármennyire is háborog a tenger.

\section{JEGYZET}

1 Az IMF és más intézmények éves előrejelzései mellett folyamatosan nyomon követik az adott évben várható GDP-változásokat. Jelen tanulmányban a felhasznált irodalomban megadott, az IMF 2019. évi GDP-elörejelzését használjuk az elemzésünkhöz, vagyis mind a versenyképességi, mind a GDP-prognózisok tekintetében az éves elôrejelzések összevetését végzi el a tanulmány.

\section{FELHASZNÁLT IRODALOM}

ÁSZ (2008): Jelentés a gazdaságfejlesztés állami eszközrendszere müködésének ellenôrzésérôl. 0802. sz., Állami Számvevôszék.

Baksay Gergely - Palotai Dániel - Szalai Ákos (2017a): Mennyire objektív a WEF versenyképességi rangsora? Egy mértékadó versenyképességi rangsor gyengeségei. www.mnb.hu/letoltes/baksay-gergely-palotai-daniel-szalai-akos-mennyire-objektiv-a-wef-mnbhonlapra.pdf.

Baksay Gergely - Palotai Dániel (2017b): Válságkezelés és gazdasági reformok Magyarországon, 2010-2016. Közgazdasági Szemle, 64. évf, 7-8. sz., 698-722, https://doi.org/10.18414/ksz.2017.7-8.698.

BCG (2014): Creating People Adventage 2014-2015. The Boston Consulting Group, www.eapm.org/wp-content/uploads/2014/12/BCG_Creating_People_Advantage_2014-2015.pdf.

EC (2019): Eurostat Regional Yearbook 2019. European Commission, Luxembourg.

Eurostat (2019): Regional GDP per capita ranged from $31 \%$ to $626 \%$ of the EU average in 2017. https:// ec.europa.eu/eurostat/web/products-press-releases/-/1-26022019-AP.

Forbes (2019): Global 2000. Forbes, www.forbes.com/global2000/\#265bf2fb335d.

IMD (2018): IMD World Talent Ranking 2018. IMD World Competitiveness Center, Lausanne, www.imd.org/ wcc/world-competitiveness-center-rankings/talent-rankings-2018/.

IMD (2019): IMD World Competitiveness Yearbook 2019. IMD World Competitiveness Center.

IMF (2019): GDP Indicators 2019. International Monetary Fund, http://statisticstimes.com/economy/ gdp-indicators-2019.php.

KSH (2019): Magyarország 2018. Központi Statisztikai Hivatal, Budapest, www.ksh.hu/docs/hun/xftp/idoszaki/mo/mo2018.pdf.

Lambert Gábor (2019): A versenyképességi reformpolitika folytatása nemzeti érdek, míg eredményei nemzeti értékké válhatnak. Interjú Palotai Dániellel az MNB 330 pontból álló versenyképességi programjáról. Biztosítás és Kockázat, 6. évf., 2. sz., 6-17, https://doi.org/10.18530/bk.2019.2.6.

Lentner, Csaba (2007): The Competitiveness of Hungarian University-Based Knowledge Centres in European Economic and Higher Education Area. Transformations In Business $\mathcal{E}$ Economics, Vol. 6, No. 2, 87-100.

Lentner Csaba (2015): Az új magyar állampénzügyi rendszer - történeti, intézményi és tudományos összefüggésekben. Pénzügyi Szemle, 60. évf., 4. sz., 485-472.

Lentner Csaba (2019): Versenyképesség. Főszerkesztôi beköszöntô. Polgári Szemle, 15. évf., 1-3. sz., 2019, 7-10, https://doi.org/10.24307/psz.2019.0901.

Lentner Csaba - Novoszáth Péter - Sági Judit (2017): A magyar családpolitika és a születésszám alakulásának egyes kiemelt területei demográfiai, szociológiai és állampénzügyi vetületben, nemzetközi kitekintéssel. Pro Publico Bono - Magyar Közigazgatás, 5. évf., 4. sz., 106-133.

Magyarország Kormánya (2019): Magyarország 2019. évi Nemzeti Reform Programja. Magyarország Kormánya, 2019. április.

Matolcsy György (2015): Egyensúly és növekedés. Konszolidáció és stabilizáció Magyarországon, 2010-2014. Kairosz Kiadó, Budapest. 
Matolcsy György - Palotai Dániel (2019): Felzárkózási pályán Magyarország. Hitelintézeti Szemle, 18. évf., 3. sz., 5-28, https://doi.org/10.25201/hsz.18.3.528.

MNB (2014): Társadalmi Felelôsségvállalási Stratégia. Magyar Nemzeti Bank, Budapest, 2014. június.

MNB (2019): Versenyképességi Program 330 pontban. Magyar Nemzeti Bank, Budapest

Nemzeti Versenyképességi Tanács (2019): Program a versenyképesebb Magyarországért. Magyarország Kormánya, www.kormany.hu/download/7/91/91000/Program\%20a\%20Versenyk\%C3\%A9pesebb\%20Magyarorsz\%C3\%A1g\%C3\%A9rt.pdf\#!DocumentBrowse.

Probst, Julius (2019): Seven Reasons Why The World Is Improving. BBC, 11 January, www.bbc.com/future/ story/20190111-seven-reasons-why-the-world-is-improving.

QS Top Universities (2019): QS World University Rankings. www.topuniversities.com/university-rankings/ world-university-rankings/2020.

Simon József - Lengyel Viktor (2017): Objektívek-e a versenyképességi rangsorok? Pénzügyi Szemle online, 2017. november 2., www.penzugyiszemle.hu/hirek/objektivek-e-a-versenykepessegi-rangsorok.

Thom Norbert - Zöldréti Attila (2019): Ajánlások a gyakornok (trainee) programok sikeres lebonyolításához. Munkaügyi Szemle, 62. évf., 6. sz., 62-69.

UN (2019): World Population Prospects 2019. United Nations, https://population.un.org/wpp/Publications/Files/WPP2019_Volume-I_Comprehensive-Tables.pdf.

WEF (2017): The Global Competitiveness Report 2016-2017. World Economic Forum, www.weforum.org/reports/the-global-competitiveness-report-2016-2017-1.

WEF (2018): The Global Competitiveness Report 2018. World Economic Forum, https://www.weforum.org/ reports/the-global-competitveness-report-2018

WEF (2019): The Global Competitiveness Report 2019. World Economic Forum, http://www3.weforum.org/ docs/WEF_TheGlobalCompetitivenessReport2019.pdf.

World Bank (2019): Doing Business 2019. Training for Reform. The World Bank, www.doingbusiness.org/ content/dam/doingBusiness/media/Annual-Reports/English/DB2019-report_web-version.pdf. 